\title{
La aplicación de las nuevas tecnologías apps en el sistema financiero ecuatoriano. Un factor que contribuye a su desarrollo
}

The application of new Apps technologies in the Ecuadorian financial system. A factor that contributes to their development

A aplicação de novas tecnologias de aplicativos no sistema financeiro equatoriano. Um fator que contribui para o seu desenvolvimento

\author{
Erlinda Elisabeth Jiménez Silva \\ Facultad de Ciencias Económicas y \\ Sociales, Postgrado en Ciencias Conta- \\ bles, Universidad de los Andes Mérida, \\ Venezuela. \\ Departamento de Ciencias Económicas, \\ Administrativas y del Comercio, Univer- \\ sidad de las Fuerzas Armadas extensión \\ Latacunga, Ecuador. \\ E-mail:eejimenez@espe.edu.ec
}

Fecha de recepción: 02/05/2018 Fecha de aceptación: 25/06/2018
Palabras clave

- Apps

- Nuevas tecnologías

- Sistema financiero

- Desarrollo económico

\section{Resumen}

El constante avance tecnológico del siglo XXI y la globalización de los mercados exigen al sector empresarial que sus actividades se enmarquen en un alto nivel de innovación y competitividad, de manera especial las organizaciones que ofrecen servicios, donde el grado de percepción sobre oportunidad, comodidad y facilidad es muy apreciado por sus clientes 0 usuarios.

El presente artículo es el resultado de una investigación en el sistema financiero ecuatoriano sobre el uso de las nuevas tecnologías, de manera particular las apps, como herramienta tecnológica en sus actividades tanto con clientes internos como externos, durante el año 2017, con la finalidad de conocer el verdadero aporte de esta herramienta en su desarrollo económico, a través del incremento de su participación de mercado y mejora en la satisfacción del cliente.

A través de una investigación cuantitativa, y mediante la aplicación de encuestas administradas a una muestra de directivos de las instituciones 
financieras entre bancos del sector privado, sector público, cooperativas y mutualistas, sobre el uso de la tecnología y de manera particular de las apps por parte de los clientes externos e internos y con el afianzamiento de información documental, se buscó analizar y comprender el efectivo aporte de las apps en su crecimiento económico. Se obtuvo así que las entidades que han logrado mayor participación en el mercado financiero son los bancos y son los que utilizan en mayor escala esta herramienta tecnológica, lo que les ha permitido disminuir costos y gastos operativos. Con ello han logrado mayor cobertura de mercado, por lo que notablemente es uno de los factores que aportan en la rentabilidad de estas entidades.

\begin{abstract}
The continuous technological advance of the 21st century and the globalization of markets require high levels of innovation and competitiveness in the business sector. These are especially required from organizations that offer services, whose customers or users value the degree of opportunity, comfort and ease.

This article is the result of a research on the use of new technologies in the Ecuadorian financial system: the use of apps as a technological tool with both internal and external clients during 2017, in order to find out their real contribution to the economic development of the financial system through the increase of market share and improvement in customer satisfaction.

In order to analyze and understand the real contribution of apps to economic growth, this quantitative research consisted in the administration of surveys among a sample of financial institutions' executives, including banks in the private sector, public sector, cooperatives and mutualists.

The surveys gathered data about the use of technology (especially of apps) by external and internal clients and they were complemented with the documentary information. Results have shown that banks are the entities which have achieved the greatest participation in the financial market, and these are the organizations which use this technological tool on a larger scale. The use of apps has allowed banks to reduce costs and operating expenses as well as to achieve greater market coverage. Therefore, it can be concluded that it is a factor which contributes to banks' profitability.
\end{abstract}

Keywords

- Apps

- New technologies

- Financial system

- Economic development

\section{Resumo}

0 constante avanço tecnológico do século XXI e a globalização dos mercados, exigem ao setor empresarial que as suas atividades sejam enquadradas em um alto nível de inovação e competitividade, de maneira especial as organizações que oferecem serviços, onde 0 grau de percepção sobre oportunidade, comodidade e facilidade é muito apreciado por seus clientes e usuários. 
Palavras-chave

- Aplicativos

- Novas tecnologias

- Sistema financiero

- Desenvolvimento económico
0 presente artigo é o resultado de uma pesquisa no sistema financeiro equatoriano sobre 0 uso das novas tecnologias, de maneira particular os aplicativos, como ferramenta tecnológica nas suas atividades, tanto com clientes internos como externos durante 0 año 2017, com a finalidade de conhecer 0 verdadeiro aporte desta ferramenta em seu desenvolvimento económico, através do acréscimo da sua participação de mercado e melhoramento na satisfação do cliente.

Através de uma pesquisa quantitativa, por meio da aplicação de enquetes administradas a uma amostra de diretivos das instituições financeiras, entre bancos do setor privado, setor público, cooperativas e mutualistas, sobre 0 uso da tecnologia, e de maneira particular dos aplicativos por parte dos clientes externos e internos e, com 0 afiançamento de informação documental, procurou-se analisar e compreender 0 efectivo aporte dos aplicativos em seu crescimento económico. Obteve-se do estudo que as entidades que têm conseguido maior participação no mercado financeiro são os bancos. Estas organizações são as que utilizam em maior escala esta ferramenta tecnológica, o que têm Ihes permitido diminuir custos e gastos operacionais, assim como também têm conseguido maior cobertura de mercado, portanto, notavelmente é um dos fatores que aportam na rentabilidade destas entidades. 